\title{
ПСИХОЛОГІЧНА КОНЦЕПЦІЯ РОЗВИТКУ ЕМОЦІЙНОГО ІНТЕЛЕКТУ ОСОБИСТОСТІ В ОНТОГЕНЕЗІ
}

\author{
Марія Шпак \\ доктор психологічних наук, доцент, \\ професор кафедри психології розвитку та консультування \\ Тернопільський національний педагогічний університет імені Володимира Гнатюка \\ 46027, Україна, м. Тернопіль, вул. Максима Кривоноса, 2 \\ shpakmariia@gmail.com, https://orcid.org/0000-0001-7073-4673
}

\section{Анотація}

У статті обгрунтовано концептуальні основи розвитку емоційного інтелекту в онтогенезі, визначено теоретико-методологічні підходи, які дають змогу створити цілісне уявлення про сутність емоційного інтелекту людини з точки зору: системного підходу (природа, структура, функції, психологічні механізми розвитку, форми i рівні розвитку в онтогенезі); суб'єктно-діяльнісного підходу (через характеристику основних структурних компонентів діяльності - мотиваційного, змістового, операційного та результативного; визначення сенситивного періоду - найбільш сприятливого для розвитку емоційного інтелекту; аналіз особливостей його прояву в суб'єкта діяльності); особистісноорієнтованого підходу (через прояв індивідуально-психологічних особливостей розвитку емоційного інтелекту); компетентнісного підходу (шляхом розвитку i формування емоційної компетентності молодших школярів, учителів початкових класів, шкільних психологів, батьків учнів).

Визначено, що емоційний інтелект $є$ інтегральною властивістю особистості, яка відображає пізнавальну здатність людини до розуміння емоцій та управління ними шляхом когнітивної обробки емоційної інформації та забезпечує психологічне благополуччя особистості й успішність соціальної взаємодії. Відповідно до рівнів психічного відображення (сенсорно-перцептивного, когнітивного, особистісного, суб'єктного, духовного) виокремлено форми (емоційний інтелект як властивість: індивіда, суб'єкта діяльності, особистості, суб'єкта життєтворчості, суб'єкта життєдіяльності), психологічні механізми (ідентифікація, наслідування, емоційне зараження, рефлексія, емоційна децентрація, емоційна саморегуляція, антиципація, емпатія), критерії та рівні розвитку емоційного інтелекту в онтогенезі (психофізіологічний, когнітивний, соціопсихологічний, креативно-суб'єктний, екзистенційно-духовний). На основі результатів емпіричного дослідження здійснено порівняльний аналіз особливостей розвитку емоційного інтелекту в старшому дошкільному, молодшому шкільному і підлітковому віці. Доведено, що молодший шкільний вік $є$ сенситивним періодом розвитку емоційного інтелекту.

Ключові слова: емоційний інтелект, розвиток, онтогенез, структурні компоненти, розуміння емоцій, управління емоціями. 


\section{Вступ}

Феномен емоційного інтелекту особистості набуває сьогодні особливої популярності та привертає до себе увагу багатьох вітчизняних і зарубіжних дослідників. При цьому впродовж останніх років зростає підвищений інтерес до емоційного інтелекту не лише у психології, а й у соціології, педагогіці, медицині, сферах управління та бізнесу. Це зумовлено, на нашу думку, низкою чинників:

1) соціально-психологічним: емоційний інтелект визнано особистісним ресурсом забезпечення ефективності спілкування, міжособистісної взаємодії, успішності життєдіяльності людини загалом (Четверик-Бурчак, 2015; Goleman, 1995), через розвиток здатності до розуміння, контролю і регуляції емоцій, мотивації, емпатії та соціальної взаємодії (Goleman, 1995);

2) соціально-економічним: ще в 2014 році на Всесвітньому економічному форумі в Давосі йшлося про взаємозв'язок емоційного інтелекту з успішністю професійної діяльності особистості, зокрема, у професіях соціономічного типу;

3) психолого-педагогічним: у контексті концепції Нової української школи емоційний інтелект визначено однією із ключових компетентностей, яка має бути сформована в учнів, зокрема молодших школярів упродовж освітньо-виховного процесу.

В сучасних психологічних дослідженнях основний фокус уваги дослідників спрямований на розуміння сутності цього феномена та виокремлення його структурних компонентів. Емоційний інтелект трактують, як: сукупність когнітивних здібностей до ідентифікації, розуміння та управління емоціями (Salovey \& Mayer, 1990); сукупність інтелектуальних здібностей до розуміння емоцій та управління ними, а також знань, умінь i навичок, операцій i стратегій інтелектуальної діяльності, пов'язаних із обробкою i перетворенням емоційної інформації (Андреева, 2011).

В структурі емоційного інтелекту J. Mayer i P. Salovey виокремили чотири компоненти: 1) сприймання, оцінка i прояв емоцій; 2) фасилітація мислення використання емоцій для підвищення ефективності мислення та діяльності; 3) розуміння емоцій; 4) управління емоціями (Mayer \& Salovey, 1993).

Д. В. Люсін розробив теоретичну модель емоційного інтелекту, в структурі якого він виокремив внутрішньоособистісний, спрямований на розуміння власних емоцій та управління ними, і міжособистісний емоційний інтелект, спрямований, відповідно, на розуміння чужих емоцій та управління ними (Люсин, 2004). Додамо, що ця теоретична модель покладена в основу опитувальника ЕмІн, розробленого Д. В. Люсіним 3 метою психодіагностичного вимірювання рівня розвитку емоційного інтелекту (Люсин, 2006).

Операціоналізації емоційного інтелекту та його структурно-функціональному аналізу сприяють результати досліджень О. І. Власової, С. П. Дерев’янко, Н. В. Ковриги, Е. Л. Носенко (Власова, 2005; Дерв'янко, 2009; Коврига, 2003; Носенко, 2003). 3'ясовано залежність рівня розвитку емоційного інтелекту від низки соціально-психологічних чинників (віку, професійної діяльності, досвіду роботи, академічної успішності навчання) (Shipley, Jackson \& Segrest, 2010).

Ми погоджуємося $з$ думкою J. Мауеr, одного з найбільш відомих зарубіжних дослідників цього феномена, який зазначив, що на сучасному етапі співіснує «два» емоційних інтелекти: один з них, «популярний» інтелект, який по-різному визначається авторами, але при цьому вони єдині у тому, що саме він найбільшою мірою забезпечує 
успіх людини в житті й може швидко набуватися, а «другий» емоційний інтелект є науковим феноменом (Mayer, 2000: 412). Тому, сьогодні важливим є саме цілісне наукове уявлення, розуміння й осмислення емоційного інтелекту особистості, що дозволить досягти ефективного його розвитку в онтогенезі. Це спонукало нас до більш докладного вивчення та концептуалізації феномена емоційного інтелекту особистості.

Мета дослідження полягає у теоретико-методологічному обгрунтуванні психологічної концепції розвитку емоційного інтелекту в онтогенезі. Завдання дослідження: 1) теоретично обгрунтувати сутність емоційного інтелекту особистості; 2) визначити наукові підходи до концептуалізації розвитку емоційного інтелекту особистості в онтогенезі; 3) емпірично визначити рівні розвитку емоційного інтелекту в старшому дошкільному, молодшому шкільному i підлітковому віці, здійснити порівняльний аналіз отриманих результатів.

\section{Методи дослідження}

Ми намагалися створити у класичному розумінні цілісне уявлення про сутність емоційного інтелекту людини з точки зору: системного niдxоду (природа, структура, функції, психологічні механізми розвитку, форми і рівні розвитку в онтогенезі); суб'єктно-діяльнісного підходу (через характеристику основних структурних компонентів діяльності - мотиваційного, змістового, операційного та результативного; визначення сенситивного періоду - найбільш сприятливого для розвитку емоційного інтелекту; аналіз особливостей його прояву в суб'єкта діяльності, зокрема, в контексті навчальної діяльності, як провідної у молодшому шкільному віці (Давыдов, Слободчиков \& Цукерман, 1992)); особистісно-орієнтованого підходу (через прояв індивідуальнопсихологічних особливостей розвитку емоційного інтелекту); компетентнісного підходу, який визнано одним із пріоритетних напрямів модернізації національної системи освіти загалом і початкової школи, зокрема, (шляхом розвитку і формування емоційної компетентності молодших школярів, учителів початкових класів, шкільних психологів, батьків учнів).

Означені наукові підходи $є$, на нашу думку, провідними у вивченні емоційного інтелекту і мають взаємодоповнювати один одного. Їх сукупність дає змогу обгрунтувати концептуальні основи розвитку емоційного інтелекту особистості в онтогенезі.

Емоційний інтелект ми розглядаємо, як інтегральну властивість особистості, що віддзеркалює пізнавальну здатність людини до розуміння емоцій й управління ними шляхом когнітивної обробки емоційної інформації та забезпечує психологічне благополуччя особистості та успішність соціальної взаємодії.

Для обгрунтування концептуальних основ розвитку емоційного інтелекту в онтогенезі було використано комплекс методів: а) теоретичні - аналіз, порівняння, узагальнення, систематизація, структурування і моделювання; б) емпіричні спостереження, бесіда, психодіагностичні методики: «Домальовування: світ речей - світ людей - світ емоцій», «Три бажання», «Що - чому - як» (Нгуен, 2008) - для дослідження рівня розвитку емоційного інтелекту в старших дошкільників; опитувальник «ЕмІн» (Люсин, 2006) - для з'ясування інтегрального показника рівня сформованості емоційного інтелекту та його структурних складових у молодших школярів і підлітків. Вибірка 
досліджуваних склала 364 особи, 3 них: 90 - старші дошкільники, 126 - молодші школярі (учні 4 класу), 148 - підлітки (учні 5-6 класів).

\section{Результати та дискусії}

I. М. Андрєєва стверджує, що і в ієрархічній структурі емоційного інтелекту можна виокремити: інтелект індивіда (ЕI як здібність (властивість функціональної системи), інтелект суб'єкта діяльності (емоційну компетентність), інтелект особистості (емоційну креативність) (Андреева, 2011). У контексті авторського дослідження це положення набуває фундаментального значення, тому вважаємо за доцільне розширити і доповнити згадану вище класифікацію форм розвитку емоційного інтелекту.

Згідно з рівнями психічного відображення (сенсорно-перцептивним, когнітивним, особистісним, суб'єктним, духовним), нами виокремлено форми (емоційний інтелект, як властивість індивіда, суб'єкта діяльності, особистості, суб'єкта життєтворчості й суб'єкта життєдіяльності) та рівні розвитку емоційного інтелекту в онтогенезі (психофізіологічний, когнітивний, соціопсихологічний, креативно-суб'єктний, екзистенційно-духовний).

Психофізіологічний рівень $є$ найнижчим у розвитку емоційного інтелекту та розкриває його природну, біологічну сутність. На цьому рівні емоційний інтелект виявляється, як емоційні властивості індивіда (емоційна чутливість, виразність (експресивність), емоційна стійкість), що презентують формально-динамічні параметри емоційних переживань (силу, інтенсивність, тривалість, швидкість перебігу), якісні характеристики (модальність і знак емоційного переживання) та змістові характеристики, які стосуються суб'єкта переживань. Функціонування емоційного інтелекту на цьому рівні у віці немовляти та в ранньому дитинстві забезпечується психологічними механізмами, що мають рефлекторний характер (ідентифікація, наслідування, емоційне зараження, співпереживання) і виникли на сенсорно-перцептивному рівні психічного відображення.

На когнітивному рівні емоційний інтелект виявляється у здатності людини розуміти та управляти своїми емоціями і віддзеркалюють когнітивний рівень психічного відображення. Емоційне самопізнання забезпечується такими психологічними механізмами, як інтелектуальна та особистісна рефлексія, а управління емоціями емоційною саморегуляцією. Як і здібності, що розвиваються на базі природних задатків індивіда, емоційні знання, уміння і навички набуваються у процесі життєдіяльності людини, ऑiі цілеспрямованого навчання i виховання та презентують іiі емоційну компетентність, яка виявляється у конкретній діяльності. 3 огляду на це, на когнітивному рівні емоційний інтелект як властивість суб'єкта діяльності передбачає вияв емоційних здібностей індивіда в конкретній діяльності, зокрема: в дошкільному віці - ігровій, молодшому шкільному віці - навчальній. Вони забезпечують успішність та якісно своєрідне освоєння і реалізацію діяльності.

На соціопсихологічному рівні емоційний інтелект, як властивість особистості, виявляється у здатності розуміти та управляти емоціями інших людей, що забезпечує ефективність спілкування і міжособистісної взаємодії з оточуючими (Журавльова \& Шпак, 2015). Такі психологічні механізми, як особистісно-смислова емпатія, емоційна децентрація, комунікативна і кооперативна рефлексія, забезпечують функціонування емоційного інтелекту на особистісному рівні психічного відображення, насамперед, у підлітковому віці. 
Креативно-суб'єктний рівень розвитку емоційного інтелекту в онтогенезі пов'язаний 3 емоційною креативністю особистості, як вищою формою емоційноінтелектуальної активності людини, що спрямована на перетворення внутрішнього світу 3 метою емоційної самозміни. Вона зумовлюється психологічним механізмом антиципації, що забезпечує здатність передбачити наслідки своїх емоційних реакцій до того, як вони будуть реально виявлені, готовність до змін емоціогенних ситуацій на основі емоційного досвіду. В процесі міжособистісної взаємодії емоційна креативність зумовлена розвиненою особистісно-смисловою емпатією, тобто внутрішньою готовністю або реальним сприянням допомогти іншому. Результатом емоційної креативності особистості $\epsilon$ гармонізація емоційного середовища (внутрішнього i зовнішнього) шляхом самотворення людиною емоційного простору. Отже, емоційна креативність спрямована на емоційний простір як сферу творчого прояву нових, ефективних й автентичних емоційних реакцій (Averill, 2004). На креативно-суб'єктному рівні емоційний інтелект найбільш інтенсивно розвивається в юнацькому віці.

Вершиною розвитку емоційного інтелекту людини як суб'єкта життєдіяльності є екзистенційно-духовний рівень, пов'язаний 3 досягненням особистістю емоційноінтелектуальної зрілості, яка виявляється в духовних переживаннях - істини, добра, краси, любові. Ціннісно-смислова рефлексія, трансфінітна емпатія, що забезпечують функціонування емоційного інтелекту на цьому рівні, сприяють надчуттєвому проникненню особистості у внутрішній світ іншої людини, проживанню цього світу, як власного, забезпечують духовну єдність зі світом та іншими людьми, i, як наслідок, дають змогу наблизитися до проблеми переживання власних особистісних смислів і цінностей. Досягнути екзистенційно-духовного рівня розвитку емоційного інтелекту людина може в дорослому віці.

Отож, у нашому розумінні емоційний інтелект виявляється на різних рівнях психічного відображення, які утворюють ієрархічно структуровану систему. Кожен рівень виконує свою необхідну роль і забезпечує цілісне функціонування і розвиток емоційного інтелекту в онтогенезі (див. рис. 1).

Такий концептуально новий підхід до феномена емоційного інтелекту та його ієрархічної структури дозволяє частково зменшити гостроту дискусії між дослідниками, котрі розглядають емоційний інтелект i, як інтелектуальну здібність, i, як властивість особистості. Адже, як видно $з$ рис. 1, це різні форми та рівні розвитку емоційного інтелекту в онтогенезі, виокремлені та теоретико-методологічно обгрунтовані нами. Також, з позицій нашого наукового трактування, розв'язується питання про можливість розвитку емоційного інтелекту, яке викликало суперечку між прихильниками моделі здібностей і змішаної моделі емоційного інтелекту, оскільки при такому підході зрозуміло, що емоційна компетентність, емоційна креативність, емоційно-інтелектуальна зрілість особистості не є вродженими властивостями людини, а розвиваються у процесі іiі життєдіяльності. 3 огляду на це, ми вважаємо правомірною точку зору тих дослідників, які стверджують про те, що емоційний інтелект можна розвивати впродовж життя людини (Goleman, 1995; Дерев'янко, 2009). 


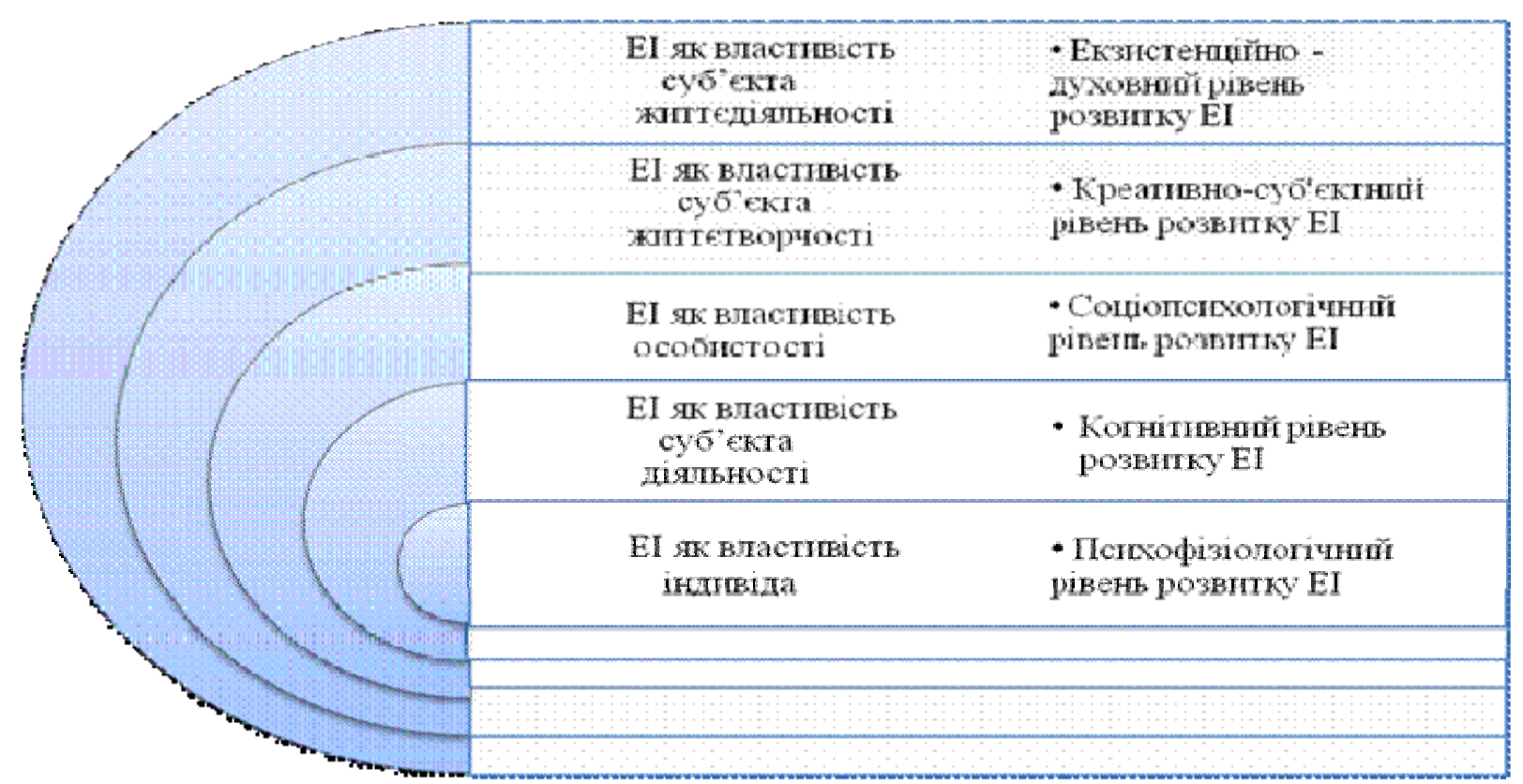

Рис. 1. Взаємозв'язок форм і рівнів розвитку емоційного інтелекту в онтогенезі

Отже, в системі психічного відображення емоційний інтелект розглядається як феномен, що має біопсихосоціодуховну природу, та $є$ багатовимірним, ієрархічно структурованим системним утворенням (Шпак, 2016).

3 огляду на окреслене вище, нами проведено емпіричне дослідження, визначено й проаналізовано психологічні особливості та рівні розвитку емоційного інтелекту в дітей старшого дошкільного, молодшого шкільного та підліткового віку.

Після проведення психодіагностичних методик, зазначених вище, та обробки отриманих даних ми здійснили порівняльний аналіз результатів дослідження становлення та розвитку емоційного інтелекту на тих вікових етапах, що межують з молодшим шкільним віком, що дало можливість врахувати ті біологічні та соціальні передумови, які склалися у дошкільному віці, та є основою для його подальшого розвитку в молодших школярів, і простежити наступність у розвитку емоційного інтелекту в підлітковому віці.

Побудована діаграма (див. рис. 2) наочно розкриває загальний рівень розвитку емоційного інтелекту в старших дошкільників, молодших школярів і підлітків.

Як видно 3 рис. 2, у більшості дітей старшого дошкільного віку переважають низький $(56,7 \%)$ і середній $(34,4 \%)$ рівні розвитку емоційного інтелекту, найменша кількість осіб - з високим рівнем емоційного інтелекту (8,9\%). Водночас варто зазначити, що у старших дошкільників поступово розвивається здатність розуміти власні емоції, хоча дитина ще не завжди може ідентифікувати емоцію за експресивними ознаками, відчуває труднощі у іiі вербалізації, однак вона починає орієнтуватися у власних емоційних переживаннях. У цьому віці починає розвиватися емпатія, хоч вона ще не є досить стійкою, однак дитина вже здатна виявляти співпереживання і співчуття, що забезпечує налагодження емоційних контактів 3 однолітками в процесі ігрової діяльності. Все це закладає сприятливий грунт для подальшого розвитку емоційного інтелекту в молодшому шкільному віці. Встановлено, що серед молодших школярів лише 11,1\% учнів мають високий рівень розвитку емоційного інтелекту. У третини досліджуваних (34,9\% учнів) - 
середній рівень розвитку емоційного інтелекту. Більше половини молодших школярів (54\% учнів) мають низький рівень розвитку емоційного інтелекту.

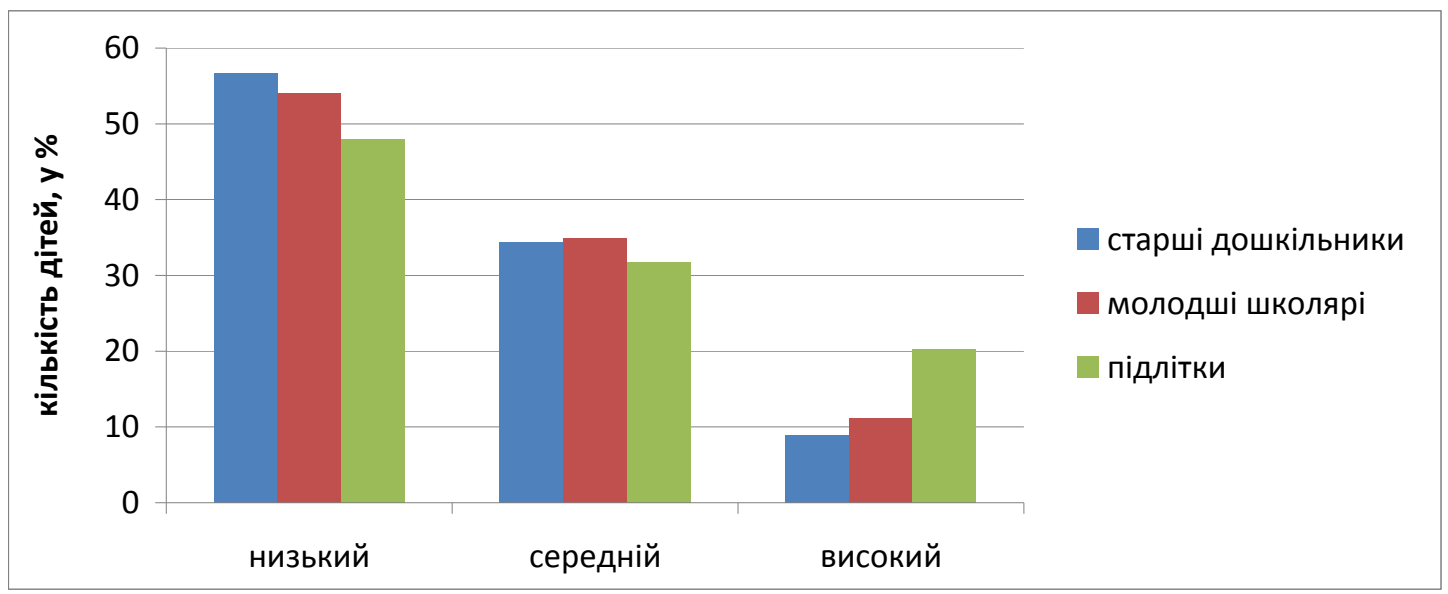

Рис. 2. Показники рівня розвитку емоційного інтелекту в старших дошкільників, молодших школярів та підлітків

Відтак, порівняно зі старшими дошкільниками, у цьому віці зменшується кількість дітей $з$ низьким рівнем розвитку емоційного інтелекту (на 2,7\%) та поступово зростає частка дітей з високим рівнем емоційного інтелекту (на 2,2\%). Водночас, відбуваються і якісні зміни у його розвитку, зокрема, зростання довільності психічних процесів, розвиток рефлексії, внутрішнього плану дій, набуття здатності до «інтелектуалізації афекту», на фоні високої емоційності дитина розпочинає усвідомлювати зміст почуттів, свідомо орієнтуватися у своїх емоціях, iї переживання набувають смислу, вони узагальнюються, формується логіка почуттів. Це дозволяє вважати цей віковий період сенситивним для розвитку емоційного інтелекту.

Якщо порівняти загальний рівень розвитку емоційного інтелекту в молодших школярів і підлітків, то варто зазначити, що він продовжує поступово зростати, зокрема, на 9,2\% збільшується кількість дітей підліткового віку з високим рівнем емоційного інтелекту і становить - 20,3\%. Це зумовлено, на нашу думку, розвитком самосвідомості й особистісної рефлексії, що сприяє кращому емоційному самоусвідомленню. У 31,7\% підлітків емоційний інтелект знаходиться на середньому рівні розвитку. Водночас, порівняно з молодшими школярами, зменшується кількість досліджуваних із низьким рівнем емоційного інтелекту (48\%), що свідчить, з одного боку, про позитивну динаміку його розвитку в процесі онтогенезу, з іншого - про те, що у молодшому шкільному віці формуються базові емоційні компетенції, які сприятливо впливають на його подальший розвиток. Одночасно встановлено, що в підлітків покращується здатність розуміти власні емоції, однак у цьому віці погіршується уміння володіти собою, керувати своїм емоційним станом, порівняно з молодшими школярами. Це зумовлено, на нашу думку, статевим дозріванням і гормональними змінами, що відбуваються в організмі підлітка, i виявляються у підвищеній емоційній збудливості, неврівноваженості, схильності до афектів, підвищеній особистісній тривожності. Отже, можемо констатувати, що найбільш сенситивним для розвитку емоційного інтелекту є молодший шкільний вік. 


\section{Висновки}

Отже, нами здійснено теоретичне й емпіричне дослідження емоційного інтелекту особистості, його генези та психологічних особливостей розвитку на засадах інтеграції системного, суб'єктно-діяльнісного, особистісно зорієнтованого і компетентнісного підходів. На теоретичному і методологічному рівнях обгрунтовано концептуальні основи розвитку емоційного інтелекту в онтогенезі, що дозволяють сформувати цілісне психологічне уявлення про емоційний інтелект людини, як багатовимірне, ієрархічно структуроване системне утворення. Згідно з рівнями психічного відображення, визначено форми (емоційний інтелект, як властивість індивіда, суб'єкта діяльності, особистості, суб'єкта життєтворчості й суб'єкта життєдіяльності), психологічні механізми (ідентифікація, наслідування, емоційне зараження, рефлексія, емоційна децентрація, емоційна саморегуляція, антиципація, емпатія), критерії та рівні розвитку емоційного інтелекту в онтогенезі (психофізіологічний, когнітивний, соціопсихологічний, креативносуб’єктний, екзистенційно-духовний). Доведено, що емоційний інтелект можна розвивати впродовж онтогенезу. Результати емпіричного дослідження і порівняльний аналіз вікових й індивідуально-психологічних особливостей розвитку емоційного інтелекту в старших дошкільників, молодших школярів і підлітків дозволяє стверджувати, що молодший шкільний вік $\epsilon$ сенситивним віковим періодом для розвитку емоційного інтелекту.

Перспективи подальших розвідок вбачаємо у вивченні взаємозв'язку емоційного інтелекту з успішністю професійної діяльності особистості, а також емпіричному вивченні рівня розвитку емоційного інтелекту в представників професій соціономічного типу.

\section{Література}

1. Андреева, И.Н. (2011). Эмоциональный интеллект как феномен современной психологии. (Монография). Новополоцк : ПГУ.

2. Власова, О.І. (2005). Психологія соціальних здібностей : структура, динаміка, чинники розвитку. (Монографія). Київ : ВПЦ «Київський університет».

3. Давыдов, В.В., Слободчиков, В.И., \& Цукерман, Г.А. (1992). Младший школьник как субъект учебной деятельности. Вопросы психологии, 3-4, 14-19.

4. Дерев'янко, С.П. (2009). Емоційний інтелект як чинник сочіально-психологічної адаптаиії особистості до студентського середовища. (Дис. канд. психол. наук). Київ.

5. Журавльова, Л.П., \& Шпак, М.М. (2015). Емпатія як психологічний механізм розвитку міжособистісного емоційного інтелекту. Science and Education a New Dimension. Pedagogy and Psychology, III (25), 49, 85-88.

6. Люсин, Д.В. (2004). Современные представления об эмоциональном интеллекте. Д.В. Люсин \& Д.В. Ушаков (Ред.), Социальный интеллект : Теория, измерение, исследования (с. 29-36). Москва : Ин-тут психологии РАН.

7. Люсин, Д.В. (2006). Новая методика для измерения эмоционального интеллекта : опросник ЭмИн. Психологическая діагностика, 4, 3-22.

8. Нгуен, М.А. (2008). Диагностика уровня развития эмоционального интеллекта старшего дошкольника. Ребенок в детском саду, 1, 83-85.

9. Носенко, Е.Л., \& Коврига, Н.В. (2003). Емоційний інтелект : концептуалізація феномену, основні функиії. (Монографія). Київ : Вища школа.

10. Четверик-Бурчак, А.Г. (2015). Механізми впливу емоиійного інтелекту на успішність життєдіяльності особистості. (Дис. канд. психол. наук). Одеса.

11. Шпак, М.М. (2016). Психологія розвитку емоційного інтелекту молодших школярів. (Монографія). Тернопіль : ТНПУ імені В. Гнатюка.

12. Averill, J.R. (2004). A tale of two Snarks : emotional intelligence and emotional creativity compared. Psychological Inquiry, 15, 228-233.

13. Goleman, D. (1995). Emotional intelligence. New York : Bantam Books. 
14. Mayer, J.D. (2000). Emotion, intelligence, emotional intelligence. In J. P. Forgas (Ed.). The handbook of affect and social cognition (pp. 410-431). Mahwah, NJ : Lawrence Erlbaum.

15. Mayer, J.D., \& Salovey, P. (1993). The Intelligence of emotional intelligence. Intelligence, 17, 433-442.

16. Salovey, P., \& Mayer, J.D. (1990). Emotional intelligence. Imagination, Cognition and Personality, 9, 185-211.

17. Shipley, N.L., Jackson, M.J., \& Segrest, S.L. (2010). The effects of emotional intelligence, age, work experience, and academic performance. Research in Higher Education Journal, 9, $1-18$.

\section{References}

1. Andreeva, I.N. (2011). Jemocional'nyj intellekt kak fenomen sovremennoj psihologii [Emotional intelligence as a phenomenon of modern psychology]. Novopolock : PGU [in Russian].

2. Vlasova, O.I. (2005). Psykholohiia sotsialnykh zdibnostei : struktura, dynamika, chynnyky rozvytku [Psychology of social skills: structure, dynamics, factors of development]. Kyiv : VPTs «Kyivskyi universytet» [in Ukrainian].

3. Davydov, V.V., Slobodchikov, V.I., \& Cukerman, G.A. (1992). Mladshij shkol'nik kak sub"yekt uchebnoj dejatel'nosti [Primary school pupil as a subject of educational activity]. Voprosy psihologii-Psychology issues, 3-4, 14-19 [in Russian].

4. Derevianko, S.P. (2009). Emotsiinyi intelekt yak chynnyk sotsialno-psykholohichnoi adaptatsii osobystosti do studentskoho seredovyshcha [Emotional intelligence as a factor of social and psychological adaptation of personality to the student's environment]. Candidate's thesis. Kyiv [in Ukrainian].

5. Zhuravlova, L.P., \& Shpak, M.M. (2015). Empatiia yak psykholohichnyi mekhanizm rozvytku mizhosobystisnoho emotsiinoho intelektu [Empathy as a psychological mechanism of the development of interpersonal emotional intelligence]. Science and Education a New Dimension. Pedagogy and Psychology, III (25), 49, 85-88 [in Ukrainian].

6. Ljusin, D.V. (2004). Sovremennye predstavlenija ob jemocional'nom intellekte [Modern concepts of emotional intelligence]. In D.V Ljusin \& D.V. Ushakov (Eds.), Social'nyj intellekt : Teorija, izmerenie, issledovanija - Social intelligence : Theory, measurement, research (pp. 29-36). Moskva : In-tut psihologii RAN [in Russian].

7. Ljusin, D.V. (2006). Novaja metodika dlja izmerenija jemocional'nogo intellekta : oprosnik JemIn [New method for measuring emotional intelligence: EmIn questionnaire]. Psihologicheskaja diagnostika - Psychological diagnostics, 4, 3-22 [in Russian].

8. Nguen, M.A. (2008). Diagnostika urovnja razvitija jemocional'nogo intellekta starshego doshkol'nika [Diagnostics of the level of the development of emotional intelligence of a senior preschooler]. Rebenok $v$ detskom sadu - A child in kindergarten, 1, 83-85 [in Russian].

9. Nosenko, E.L., \& Kovryha, N.V. (2003). Emotsiinyi intelekt : kontseptualizatsiia fenomenu, osnovni funktsii [Emotional intelligence: conceptualization of the phenomenon, main functions]. Kyiv : Vyshcha shkola [in Ukrainian].

10. Chetveryk-Burchak, A.H. (2015). Mekhanizmy vplyvu emotsiinoho intelektu na uspishnist zhyttiediialnosti osobystosti [Mechanisms of the influence of emotional intelligence on the success of a person's life]. Candidate's thesis. Odesa [in Ukrainian].

11. Shpak, M.M. (2016). Psykholohiia rozvytku emotsiinoho intelektu molodshykh shkoliariv [Psychology of the development of emotional intelligence of primary school pupils]. Ternopil : TNPU imeni V. Hnatiuka [in Ukrainian].

12. Goleman, D. (1995). Emotional intelligence. New York : Bantam Books.

13. Averill, J.R. (2004). A tale of two Snarks : emotional intelligence and emotional creativity compared. Psychological Inquiry, 15, 228-233.

14. Mayer, J.D. (2000). Emotion, intelligence, emotional intelligence. In J. P. Forgas (Ed.). The handbook of affect and social cognition (pp. 410-431). Mahwah, NJ : Lawrence Erlbaum.

15. Mayer, J.D., \& Salovey, P. (1993). The Intelligence of emotional intelligence. Intelligence, $17,433-442$. 
16. Salovey, P., \& Mayer, J.D. (1990). Emotional intelligence. Imagination, Cognition and Personality, 9, 185-211.

17. Shipley, N.L., Jackson, M.J., \& Segrest, S.L. (2010). The effects of emotional intelligence, age, work experience, and academic performance. Research in Higher Education Journal, 9, $1-18$.

\title{
PSYCHOLOGICAL CONCEPT OF THE DEVELOPMENT OF EMOTIONAL INTELLIGENCE OF THE PERSON IN ONTOGENESIS Mariia Shpak \\ Doctor of Sciences in Psychology, Associate Professor, Professor of the Department of Developmental Psychology and Consultancy \\ Ternopil Volodymyr Hnatiuk National Pedagogical University \\ 2, Maxyma Kryvonosa Str., Ternopil, Ukraine, 46027 shpakmariia@gmail.com, https://orcid.org/0000-0001-7073-4673
}

\begin{abstract}
Conceptual basis of the development of emotional intelligence in ontogenesis are grounded in the article, it is defined theoretical and methodological approaches, which allows to form a coherent consideration about the gist of emotional intelligence of the person in terms of: systemic approach (nature, structure, functions, psychological mechanisms of the development, forms and levels of the development in ontogenesis); subject-activity approach (through the characteristic of the main structural components of the activity - motivational, contextual, operational and effective; determination of the sensitive period - the most advantageous for the development of emotional intelligence; the analysis of the peculiarities of it's manifestation in the subject of an activity); personally oriented approach (through the revelation of individualpsychological peculiarities of the development of emotional intelligence); competent approach (through the development and formation of the emotional competence of primary school pupils, primary school teachers, school psychologists, parents of the pupils).

It is defined that emotional intelligence is an integral feature of the individual, which reflects the cognitive ability of a person to understand the emotions and manage them through the cognitive processing of emotional information and provides psychological well-being of the individual and the success of social interaction. According to the levels of a mental reflection (sense-perceptual, cognitive, personal, subjective, spiritual) it is determined the forms (emotional intelligence as the feature: of the individual, of the subject of an activity, of the person, of the subject of lifecreativity, of the subject of daily living activities), psychological mechanisms (identification, imitation, emotional infection, reflection, emotional decentralization, emotional self-regulation, anticipation, empathy) criteria and levels of the development of emotional intelligence in ontogenesis (psychophysiological, cognitive, socio-psychological, creatively-subjective, existential-spiritual). On the basis of the results of empirical research, it is carried out a comparative analysis of the peculiarities of the development of emotional intelligence in late preschool, primary school, and adolescence age. It is determined that the primary school age is a sensitive period of the development of emotional intelligence.
\end{abstract}

Keywords: emotional intelligence, development, ontogenesis, structural components, understanding the emotions, managing the emotions.

Подано 06.04.2020

Рекомендовано до друку 26.05.2020 